University of Nebraska - Lincoln

DigitalCommons@University of Nebraska - Lincoln

\title{
Morphological and histochemical characterization of the seminiferous epithelial and Leydig cells of the turkey
}

\author{
M. R. Bakst \\ USDA, murray@anri.barc.usda.gov \\ V. Akuffo \\ USDA \\ P. Trefil \\ BIOPHARM \\ J. P. Brillard \\ INRA
}

Follow this and additional works at: https://digitalcommons.unl.edu/usdaarsfacpub

Part of the Agricultural Science Commons

Bakst, M. R.; Akuffo, V.; Trefil, P.; and Brillard, J. P., "Morphological and histochemical characterization of the seminiferous epithelial and Leydig cells of the turkey" (2007). Publications from USDA-ARS / UNL Faculty. 617.

https://digitalcommons.unl.edu/usdaarsfacpub/617

This Article is brought to you for free and open access by the U.S. Department of Agriculture: Agricultural Research Service, Lincoln, Nebraska at DigitalCommons@University of Nebraska - Lincoln. It has been accepted for inclusion in Publications from USDA-ARS / UNL Faculty by an authorized administrator of DigitalCommons@University of Nebraska - Lincoln. 


\title{
ANIMAL \\ REPRODUCTION \\ SCIENCE
}

\section{Morphological and histochemical characterization of the seminiferous epithelial and Leydig cells of the turkey}

\author{
M.R. Bakst ${ }^{\mathrm{a}, *}$, V. Akuffo ${ }^{\mathrm{a}}$, P. Trefil $^{\mathrm{b}}$, J.P. Brillard ${ }^{\mathrm{c}}$ \\ a Biotechnology and Germplasm Laboratory, ARS, USDA, Beltsville, MD 20705, USA \\ b BIOPHARM, Research Institute of Biopharmacy and Veterinary Drugs, a.s. 25449 Jílové u Prahy, Czech Republic \\ c INRA, Station de Recherches Avicoles, 37380 Nouzilly, France
}

Received 30 December 2005; accepted 10 February 2006

Available online 18 April 2006

\begin{abstract}
Unlike mammals, there is little fundamental information about spermatogenesis in birds. This study was undertaken to clarify the morphology, histochemistry, and lectin affinity of the seminiferous epithelial cells and Leydig cells in pre-pubertal (8- to 15-week old) and adult (40- to 44-week old) domestic turkeys. In adult turkeys, three types of spermatogonia were defined based on their chromatin distribution and nuclear morphology: the dark type $A\left(A_{d}\right)$; the pale type $A\left(A_{p}\right)$; and the type $B$. The $A_{d}$ is the least numerous and least conspicuous and consequently difficult to locate. Based on its spatial distribution and overall morphology, type $A_{d}$ spermatogonia were postulated to be the spermatogonia stem cells in the turkey. Antibodies to c-kit were localized to spermatogonia in the pre-pubertal and to a lesser extent in adult males. Peanut agglutinin (PNA) was specific for spermatocytes in the pre-pubertal males and spermatogonia and early spermatocytes in adult males. Wheat-germ agglutinin (WGA) highlighted Sertoli cells in both age groups. Bandeiraea simplicifolia I, soybean agglutinin, and winged-pea agglutinin staining were limited to the wall of the seminiferous tubule and some extra-tubular cell types. Concanavalin A staining was diffuse and not cellspecific and, therefore, could not be used to selectively identify a particular cell type. It was concluded that WGA and PNA could aid in identifying specific cell types in the seminiferous epithelium of testis from prepubertal and mature turkeys. Only Leydig cells were alkaline phosphatase reactive in the mature turkey testes. The information from this study is being used to adapt techniques for the isolation and partial purification developed for mammalian spermatogonia to avian spermatogonia and other specific cell types in the testes. Published by Elsevier B.V.
\end{abstract}

Keywords: Turkey; Spermatogonial stem cells; Seminiferous epithelium

\footnotetext{
* Corresponding author at: Biotechnology and Germplasm Laboratory, Animal and Natural Resources Institute, Beltsville Area, Agricultural Research Service, USDA, Building 200, BARC-East, Powder Mill Road, Beltsville, MD 20705, USA. Tel.: +1 301504 8795; fax: +1 3015045123 .

E-mail address: murray@anri.barc.usda.gov (M.R. Bakst).
}

0378-4320/\$ - see front matter. Published by Elsevier B.V. doi:10.1016/j.anireprosci.2006.02.009

This article is a U.S. government work, and is not subject to copyright in the United States. 


\section{Introduction}

Germ cell transfer is becoming an important technique for the study of spermatogenesis and potentially can be used for the production of transgenic progeny (Dobrinski, 2005). Recently, we were able to obtain ejaculates from previously sterilized roosters after transplanting dispersed testicular cells (Trefil et al., submitted for publication). To improve the efficiency of this transfer, we are interested in developing the capacity to isolate and identify individual cells of the seminiferous epithelium (SE), particularly spermatogonia. To our knowledge, only Roca and Mezquita (1989) have described the separation of chicken testis cell nuclei by sedimentation at unit gravity and for the enrichment of elongated spermatids and spermatozoa by centrifugal elutriation. The same techniques have been used to obtain an enriched population of both round spermatids and spermatocytes (Kirby, University of Arkansas, personal communication). Rather than relying exclusively on physical techniques to separate mammalian SE cells, surface phenotypic markers are being used to select for or against a particular population of cells (Hofmann et al., 2005). This has yet to be done with avian SE cells.

Spermatogenesis is the process by which the diploid spermatogonia differentiate into the haploid sperm. In contrast to what is known in mammals, there is relatively little information regarding spermatogenesis in birds. The cytological relationships of the cells comprising the SE of several avian species have already been examined with the most comprehensive studies done on Japanese quail (Lin and Jones, 1992; Jones and Lin, 1993). Earlier work by Zlotnik (1947) and Clermont (1958) described germ cell morphology during spermatogenesis in the chicken and the duck, respectively, while Aire et al. (1980) and Brillard (1981) did the same with the guinea fowl. de Reviers (1971) described the growth of the testes and differentiation of the SE of the chicken. Differentiation of the Sertoli cell (Cooksey and Rothwell, 1973) and spermiogenesis (Gunawardana, 1977) have been investigated in the chicken. Recently, Noirault et al. (in press) showed that the SE of the turkey and the duration of meiosis are similar to that of the chicken and Guinea fowl.

Identification of specific cell types up to and including meiotic prophase in the active SE of the avian testis has been proposed by de Reviers (1971; chicken), Brillard (1981; Guinea fowl), Lin and Jones (1992; Japanese quail), Jones and Lin (1993; Japanese quail) and Noirault et al. (in press; turkey). Four types of spermatogonia were described for Japanese quail: the dark spermatogonia, type $A_{d}$, which were suggested to be the spermatogonial stem cell; two types of pale spermatogonia, types $A_{p 1}$ and $A_{p 2}$, which were intermediate stages and could only be differentiated by transmission electron microscopy (TEM); and, type B spermatogonia, which is the stage preceding primary spermatocyte formation (Lin and Jones, 1992; Jones and Lin, 1993).

In the following study, we attempt to discover surface markers and morphological characteristics that will characterize individual cell types in the turkey's SE. Plant lectins, which are most easily characterized by their affinities for specific, terminal glycosidic residues associated with glycolipids and glycoproteins, and c-kit, a known marker for mammalian spermatogonia, were evaluated for their possible use as markers for specific cell-types in the SE of the turkey. Lectins have been used to describe glycoprotein components of germ and somatic cells in the mammalian SE and to elucidate patterns of glycoprotein synthesis, secretion, and absorption in the cells of the mammalian SE and epididymis (Arya and Vanha-Perttula, 1984, 1986a,b; Arenas et al., 1998; Pastor et al., 2003). 


\section{Materials and methods}

\subsection{Animals}

Large White turkey breeders (British United Turkeys of America, Lewisburg, WV, USA) were maintained under recommended husbandry conditions. Twelve mature breeder males 40-44 weeks of age and 10 pre-pubertal males (three at 8-week; three at 13-week; four at 15-week) were euthanized with either sodium pentobarbital or cervical dislocation and their testes quickly removed for fixation or for cell dispersal.

\subsection{Histology and histochemistry}

All chemicals and reagents used in this study, except where noted elsewhere, were purchased from Sigma-Aldrich Chemical Co. (St. Louis, MO, USA). A variety of fixatives were evaluated to determine which provided optimal histological as well as histochemical results. We determined that neutral buffered formalin (NBF) was satisfactory with all procedures except the lectin histochemistry. Tissue to be used for lectin histochemistry was fixed in sublimate formalin (Bosman et al., 1977) which is composed of $55 \mathrm{~mL}$ of saturated mercuric chloride (about $6 \mathrm{~g}$ mercuric chloride in $100 \mathrm{~mL}$ of water), $5 \mathrm{~mL}$ of glacial acetic acid, and $10 \mathrm{~mL} 37-40 \%$ formalin made up before use. All testes sections were examined using a Zeiss Axioskop Microscope (Carl Zeiss, Thornwood, NY) equipped with optics for bright field, fluorescence, and differential interference contrast microscopy.

Regardless of fixative used, approximately $3 \mathrm{~mm}$ thick specimens were fixed for $18-24 \mathrm{~h}$ at $18-22{ }^{\circ} \mathrm{C}$. and after dehydration, embedded in paraplast. Tissues were sectioned at $6 \mu \mathrm{m}$, airdried and stored until staining. For orientation purposes and general histology some sections were stained with hematoxylin and eosin or periodic acid-Schiff's stain. To compare nuclear morphology of spermatogonia in histological sections to un-fixed dispersed testicular cells, Hoechst 33342 (Molecular Probes, Eugene, OR, USA; bis-benzimide) at a final concentration of $2 \mu \mathrm{g} / \mathrm{mL}$ buffer was added to the slide with sections or cell suspension at room temperature for $30-120 \mathrm{~min}$. To avoid mercuric chloride precipitation on the sections of tissues fixed with sublimate formalin, slides were placed in Lugol's iodine ( $1 \mathrm{~g}$ iodine plus $2 \mathrm{~g}$ potassium iodate in $100 \mathrm{~mL}$ of water) for $15 \mathrm{~min}$. Slides were them immersed in $5 \%$ sodium thiosulfate for $3 \mathrm{~min}$, washed in running water for $10 \mathrm{~min}$ and rinsed in distilled water.

For 1-2 $\mu \mathrm{m}$ thick sections, $2 \mathrm{~mm}$ thick testes samples were fixed in buffered $2 \%$ glutaraldehyde, dehydrated and embedded in an epoxy resin. Sections were stained with toluidine blue (1\% plus $0.1 \%$ borax). Morphological characteristics of the nuclei in each sub-type of spermatogonia were assessed in four adult testes by determining their dimensions (maximum $\times$ minimum diameter) with a micrometric scale (10 nuclei from each type/male) using an Axioplan Zeiss microscope (Carl Zeiss, Le Pecq, France).

\subsection{Lectin histochemistry}

Testes sections from mature and pre-pubertal males were histochemically analyzed for assorted lectins. Table 1 shows the lectin, its abbreviation and/or common name, concentration and the competitive sugar used for controls. Tissue sections were de-paraffinized in xylene, rehydrated in descending concentrations of alcohols, and washed in TBS containing $1 \mathrm{mM} \mathrm{CaCl}_{2}, 1 \mathrm{mM}$ $\mathrm{MgCl}_{2}$, and $1 \mathrm{mM} \mathrm{MnCl}$ plus $0.4 \%$ polyvinylpyrrolidone (PVP). Slides were covered with $3 \%$ 
Table 1

Lectins, staining concentrations, sugar specificities, and competitive sugars

\begin{tabular}{|c|c|c|c|}
\hline \multicolumn{2}{|l|}{ Lectin/agglutinin } & \multirow{2}{*}{$\begin{array}{l}\text { Concentration } \\
(\mu \mathrm{g} / \mathrm{mL})\end{array}$} & \multirow[t]{2}{*}{ Specificity (competitive sugar) ${ }^{\mathrm{a}}$} \\
\hline Taxonomic name & $\begin{array}{l}\text { Common } \\
\text { name/abbreviation }\end{array}$ & & \\
\hline Arachis hypogaea & Peanut (PNA) & 50 & $\begin{array}{l}\beta \text {-D-galactose-(1,3)- } N \text {-acetyl-galactosamine } \\
\text { (D-galacose) }\end{array}$ \\
\hline Bandeiraea Simplicifolia I & BS-I & 125 & $\begin{array}{l}\alpha \text {-D-galactose, } \alpha \text { - } N \text {-acetyl-D-galactosamine } \\
\text { (D-galactose) }\end{array}$ \\
\hline Canavalia Ensiformis & Concanavalin A (Con A) & 5 & $\begin{array}{l}\alpha \text {-D-mannose, } \alpha \text {-D-glucose } \\
\text { (methyl-D-mannoside) }\end{array}$ \\
\hline Glycine $\max$ & Soybean (SBA) & 75 & $\begin{array}{l}N \text {-acetyl-D-galactosamine } \\
\text { (N-acetyl-galactosamine) }\end{array}$ \\
\hline Tetragonolobus purpureas & Winged pea (WPA) & 200 & $\alpha$-L-fucose $(\alpha-\mathrm{L}-$ fucose $)$ \\
\hline Triticum vulgaris & Wheat germ (WGA) & 0.5 & $\begin{array}{l}N \text {-acetyl-D-glucosamine, } \\
N \text {-acetyl-neuraminic acid } \\
(N \text {-acetyl-D-glucosamine })\end{array}$ \\
\hline
\end{tabular}

a The final concentration of all competitive sugars was $0.2 \mathrm{M}$.

hydrogen peroxide for $5 \mathrm{~min}$ to quench endogenous peroxidase activity and then washed in two 5 -min changes of fresh buffer. Some sections were flooded with $0.1 \%$ protease (Sigma Type XXIV) in buffer for $5 \mathrm{~min}$, washed in two 5 min changes of fresh buffer and then flooded with $1 \%$ bovine serum albumin (BSA) in buffer for atleast $30 \mathrm{~min}$. The buffer/BSA was gently shaken off just before lectin staining. The sections were incubated $4-6 \mathrm{~h}$ at room temperature in the selected lectin in TBS plus $0.4 \%$ PVP. Sections were incubated in a peroxidase substrate solution [the Vector VIP substrate or a diamino-benzidine; Vector Laboratories (Burlingame)] and examined by bright field or fluorescence microscopy. For controls, TBS was applied to the sections with either no lectin or the lectin plus $0.2 \mathrm{M}$ of its competitive sugar (Table 1). We also incubated sections in $60 \mu \mathrm{g} / \mathrm{mL}$ of horseradish peroxidase as described for the lectins. Positive controls consisted of concurrent lectin staining of the cecal tonsil and proctodeal gland specimens isolated and prepared for microscopy in the same manner as testes samples.

\subsection{Alkaline phosphatase}

For the localization of alkaline phosphatase activity in testes sections, the BCIP/NBT (5bromo,4-chloro,3-indolylphosphate/nitroblue tetrazolium) Alkaline Phosphatase Substrate Test was performed according to the instructions provided in the Vector BCIP/NBT Kit [Catalog no. SK-5400, Vector Laboratories (Burlingame, CA)]. Briefly, the BCIP/NBT substrate working solution was prepared immediately before use and added to the sections until suitable staining developed, generally around $20-30 \mathrm{~min}$ at $18-22{ }^{\circ} \mathrm{C}$. Sections were washed in buffer for $5 \mathrm{~min}$ then rinsed in tap water. For permanent mounting the sections were dehydrated, cleared and mounted with VectaMount [Catalog no. 14-5000, Vector Laboratories (Burlingame, CA)].

\subsection{Immunocytochemistry}

Localization of c-kit, the CD117 transmembrane receptor, was accomplished using a fluorescent antibody on NBF fixed sections of testes from mature and pre-pubertal males. Five to $7 \mu \mathrm{m}$ 
thick sections were de-paraffinized in xylene, rehydrated in descending concentrations of alcohols, washed in tris-buffered saline (with $0.1 \%$ Triton $\mathrm{X}$ ) and stained with the DakoCytomation Envision + System-HRP [aminoethylcarbazole (AEC); Dako (Carpinteria, CA)]. Briefly, the steps are as follows; endogenous peroxidase activity was quenched in $0.3 \%$ hydrogen peroxide for 5 min. The sections were blocked with diluted goat or horse serum, and then incubated overnight at $5{ }^{\circ} \mathrm{C}$ with a c-kit monoclonal rabbit anti-human antibody IgG [VP-C385 VECTOR; CD117; Vector Laboratories (Burlingame, CA)], 1:20 dilution or DakoCytomation code A4502; 1:200 dilutions. Tris-buffered saline was applied instead of primary antibody as a negative control. The sections were incubated $30 \mathrm{~min}$ with anti-rabbit peroxidase polymer. Antigen-antibody complexes were visualized using an AEC + substrate-chromagen solution (according to the manufacturer's recommendations). The immunostaining results were recorded via microscopic digital image with respect to intensity and distribution of staining. Alternatively, the sections were incubated $1 \mathrm{~h}$ with a biotinylated secondary antibody. When a Vector R.T.U. Elite ABC reagent was used to detect antigen-antibody complexes, the sections were incubated in a peroxidase substrate to visualize the reaction.

\subsection{Testicular cell dispersal}

After removing the tunica albuginea, $8-10 \mathrm{~g}$ of tissue were finely minced into $1-2 \mathrm{~mm}^{3}$ pieces with a razor blade. The minced tissue was incubated in the cell dispersal media consisting of $100 \mathrm{~mL}$ D-MEM/F12, $0.1 \%$ trypsin or $200 \mathrm{ug} / \mathrm{mL}$ Collagenase [Type 1, Gibco 17100-017 (Invitrogen Corporation, Carlsbad, CA) or Type XI, Sigma C-7657], $20 \mu \mathrm{g} / \mathrm{mL}$ DNase on a shaker set at $150 \mathrm{rpm}$ at $32{ }^{\circ} \mathrm{C}$ for $30 \mathrm{~min}$. Occasionally the tissue was aspirated into a pipette and re-suspended in a rapid up and down motion. The cell dispersal was stopped with $20 \mu \mathrm{g} / \mathrm{mL}$ trypsin inhibitor and the slurry was filtered through four layers of gauze, then a $70 \mu \mathrm{m}$ nylon screen and centrifuged at $100 \times g$ for $10 \mathrm{~min}$. The pellet was recovered and re-suspended in $100 \mathrm{~mL}$ Dulbecco's Modified Eagle's Medium (MEM)/Nutrient Mixture F-12 Ham (D-MEM/F12). A cell count was performed with a hemacytometer to check viability ( $0.4 \%$ trypan blue) and determine the average number of cells recovered $\left(6.5 \times 10^{7}\right.$ cells $\left./ \mathrm{mL}\right)$. The mixture of cells was filtered again through a $20 \mu \mathrm{m}$ nylon screen before attempting to fractionate the dispersed testicular cells with a $25-37 \%$ Redigrad gradient (9:1, Redigrad to 10X MEM with Hepes modification) and a control with density marker beads alone. Both were centrifuged at $10,000 \times g$ for $20 \mathrm{~min}$. Fractions were collected and examined by removing $10-20 \mu \mathrm{L}$ of the cell suspension and placing it on a slide and added cover slip.

\section{Results}

\subsection{Seminiferous epithelium and Leydig cells}

Regardless of age of the male, the wall of the seminiferous tubule consisted of a basement membrane and connective tissue cells and fibers (Figs. 1-3, 7, 8). The connective tissue cells had an attenuated fibroblast-like appearance with long oval nuclei, which in the pre-pubertal males circumscribed a more readily apparent basement membrane (Figs. 7 and 8). Leydig cells were characterized by their round nuclei and the numerous lipid droplets typical of steroid secreting cells (Figs. 1-3). In the plastic sections individual lipid droplets were more easily discerned in contrast to the thicker paraffin sections where they had a foamy appearance (Figs. 6 and 7). Of the numerous cell types in the testes, only the Leydig cells were alkaline phosphatase positive (Fig. 4). 


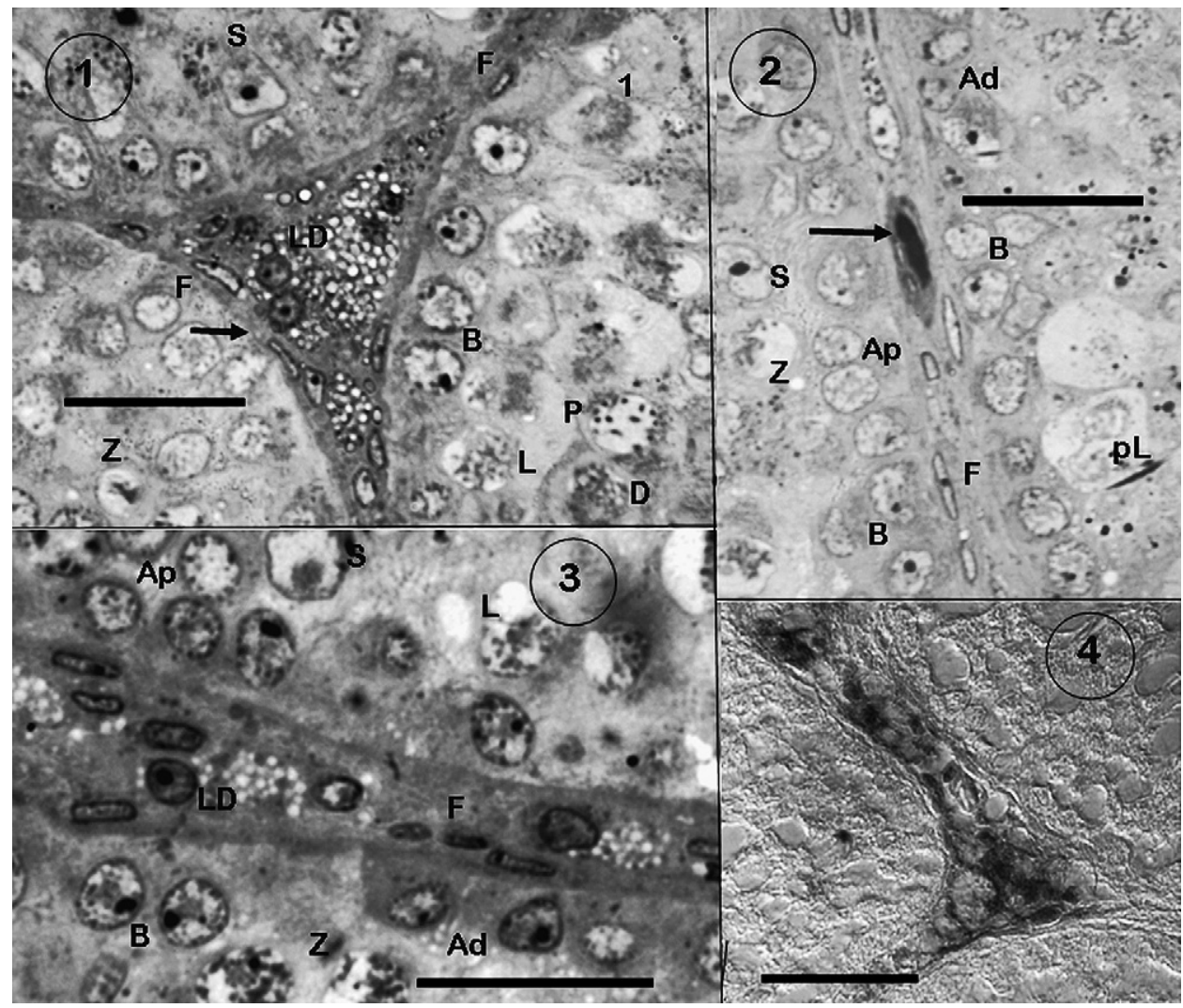

Figs. 1-4. Fig. 1. A 1-2 mm thick plastic section of the interstitial cells bounded by three seminiferous tubules from a 44-week old male is shown. Cells comprising the interstitium include fibroblast-like cells (F) and Leydig cells (LD) characterized by numerous lipid droplets. An attenuated basement membrane (arrows) separates the interstitial space from the seminiferous epithelium. Type B spermatogonia and primary spermatocytes in zygotene (Z), pachytene (P), diplotene (D) and leptotene (L) stages of meiosis are observed. S, Sertoli cell. Bar $=20 \mu \mathrm{m}$. Fig. 2 . A 1-2 mm thick plastic section of two seminiferous tubules separated by a narrow band of interstitial tissue a peritubular capillary (arrow) and fibroblast-like cells $(F)$. Type $A_{d}, A_{p}$ and $B$ spermatogonia and primary spermatocytes in zygotene (Z) and leptotene (L) stages of meiosis are observed. A pre-leptotene $(\mathrm{pL})$ spermatocyte with a pair of nuclei is observed. S, Sertoli cell. 40-week old male, Bar $=20 \mu \mathrm{m}$. Fig. 3. A 1-2 mm thick plastic section of the interstitial cells bounded by two seminiferous tubules from a 44-week old male. Cells in the interstitium include fibroblast-like cells (F) and Leydig cells (LD) characterized by numerous lipid droplets. An attenuated basement membrane (arrows) separates the interstitial space from the seminiferous epithelium. Types $A_{d}, A_{p}$ and $B$ spermatogonia and primary spermatocytes in zygotene $(Z)$ and leptotene (L) stages of meiosis are observed. S, Sertoli cell. Bar $=22 \mu \mathrm{m}$. Fig. 4 . A $6 \mathrm{~mm}$ thick paraffin section showing positive alkaline phosphatase reaction over the Leydig cells in the interstitium. 40 -week old male, Bar $=35 \mu \mathrm{m}$.

Spermatogonia were predominantly cuboidal to low cuboidal and restricted to contact with or close proximity to the inner wall of the seminiferous tubule. In the 8-week old pre-pubertal males only spermatogonia and Sertoli cells were present. At this age, part of the spermatogonia population was associated with the basement membrane of the SE but occasionally assumed a more irregular elongated appearance with their nuclei repositioned closer to the central lumen (Figs. 7 and 8). Some individual seminiferous tubules in some 13-15 week old pre-pubertal males possessed spermatocytes entering meiotic prophase. 
In adult turkeys, three types of spermatogonia were defined based on their chromatin distribution and nuclear morphology: the dark type $A\left(A_{d}\right)$; the pale type $A\left(A_{p}\right)$; and the type $B$. The $A_{d}$ was the least numerous and least conspicuous and consequently difficult to locate. As implied by its name, the $A_{d}$ sub-type was darker than the other spermatogonia, particularly after toluidine blue staining of plastic sections, and closely apposed to the basement membrane. Mean nuclear maximum $\times$ minimum diameters of the $A_{d}$ were $5.5 \mu \mathrm{m} \times 4.4 \mu \mathrm{m}$. Type $A_{d}$ possessed a single nucleolus and scattered chromatin (Figs. 2 and 3). The type $A_{p}$ was characterized by a relatively large round-to-oval nucleus (dimensions: $6.6 \mu \mathrm{m} \times 5.4 \mu \mathrm{m}$ ) containing dispersed chromatin (hence the pale appearance) and from 0 to 3 prominent nucleoli (Figs. 1-3). Unlike type $A_{d}$ spermatogonia, type $A_{p}$ cells were not exclusively associated with the basement membrane. The type $\mathrm{B}$ spermatogonia had an appearance intermediate between the other two types being somewhat darker than the $A_{p}$ spermatogonia but lighter and larger than the $A_{d}$ spermatogonia. Type $\mathrm{B}$ spermatogonia were also categorized by a round to pleomorphic nucleus (dimensions: $6.5 \mu \mathrm{m} \times 6.1 \mu \mathrm{m}$ ) possessing one or more nucleoli (Figs. 1-3).

Primary spermatocytes in the leptotene stage had begun condensation of the chromosomes and consequently relatively fine to dense chromatin filaments were dispersed throughout the nucleus (Figs. 5 and 6). In the zygotene stage, chromosomes began to thicken and become polarized (Figs. 2, 5, 6). Synapses between homologous chromosomes appear denser and were more uniformly distributed in the pachytene nucleus (Figs. 5 and 6). Diplotene nuclei possessed more compact chromosomes evenly dispersed throughout the nuclei (Fig. 6).

While secondary spermatocytes could not definitely be identified, the nuclei of the round spermatids were the smallest observed in the SE and characteristically had a small eccentric nucleoli and a thin band of heterochromatin lining the nuclear envelop (Figs. 5 and 6). Elongating spermatids were in various stages of nuclear condensation. Sertoli cells in mature males were most easily identified by their large pale nucleus with a dense nucleolus (Figs. 1-3, 5, 6). Occasionally the cytoplasm of the Sertoli cell contained clusters of lipid droplets in the vicinity of its nucleus.

\subsection{Lectin staining of the seminiferous epithelium}

\subsubsection{Controls}

Little or no staining was observed in the SE after incubation with a lectin and its corresponding competitive sugar. When incubated with horseradish peroxidase without the lectin there was a slight increase in non-specific background staining.

\subsubsection{8- to 15-week pre-pubertal males (PNA and WGA)}

The SE is composed of the pyramidal Sertoli cells and spermatogonia in the younger males and spermatogonia and primary spermatocyte in males over 10 week of age. Spermatogonia were cuboidal to round shaped and were selectively labeled intensely with PNA. Leptotene spermatocytes, which were present in a few seminiferous tubules in 8-week old pre-pubertal males (Fig. 7), and zygotene and pachytene spermatocytes, which were observed in the 12-week and older prepubertal males, also were labeled with the PNA, but less intensely than the spermatogonia. In contrast, Sertoli cells were selectively labeled with WGA, particularly in their apical cytoplasm. Isolated areas of the SE of one of the three 15 week pre-pubertal males examined possessed elongating spermatids. While the PNA labeled the spermatogonia and primary spermatocytes the same as 12-week pre-pubertal males, the WGA labeled its supranuclear cytoplasm more intensely than its apical cytoplasm. 


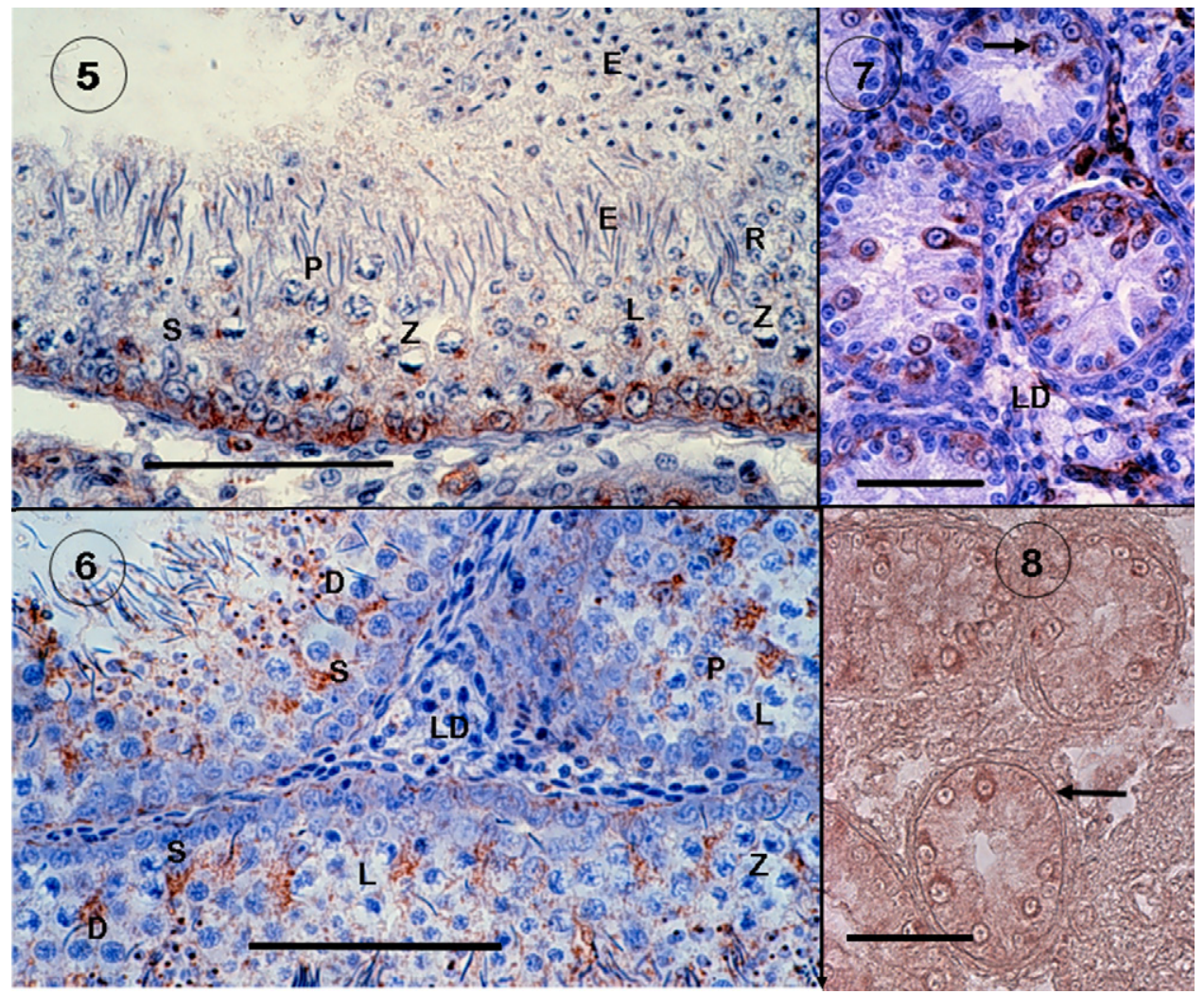

Figs. 5-8. Fig. 5. The spermatogonia and, to a lesser extent, early primary spermatocytes are PNA positive. The spermatogonial sub-types cannot be differentiated. However, primary spermatocytes in zygotene $(\mathrm{Z})$, pachytene $(\mathrm{P})$ and leptotene (L) stages of meiosis are observed in this $6 \mu \mathrm{m}$ thick section. Round (R) and elongated spermatids (E) are visible. S, Sertoli cell. 40 -week old male. Bar $=70 \mu \mathrm{m}$. Fig. 6. Sertoli cell cytoplasm is highlighted by WGA while the remaining cells of the seminiferous epithelium show no binding with the WGA. Primary spermatocytes in zygotene (Z), pachytene $(\mathrm{P})$, diplotene (D), and leptotene (L) stages of meiosis are observed in this $6 \mu \mathrm{m}$ thick section. Round (R) and elongated spermatids (E) are visible. S, Sertoli cell; LD, Leydig cells; 40-week old male. Bar $=70 \mu \mathrm{m}$. Fig. 7. Observed in this $6 \mu \mathrm{m}$ thick section are cross-sections of seminiferous tubules from an 8-week old pre-pubertal male revealing the dense binding of PNA to spermatogonia. The unstained cells with smaller nuclei within the seminiferous tubules are Sertoli cells. The lipid component of the Leydig (LD) cells has a foamy appearance. Arrow, spermatocyte. Bar $=35 \mu \mathrm{m}$. Fig. 8. Cross-sections of seminiferous tubules from 8-week old pre-pubertal male reveal the c-kit positive spermatogonia in this $6 \mu \mathrm{m}$ thick section. The unstained cells with smaller nuclei within the seminiferous tubules are Sertoli cells. Arrow, basement membrane. $\mathrm{Bar}=35 \mu \mathrm{m}$.

\subsubsection{0- to 44-week}

In the SE producing sperm, PNA stained the cytoplasm of the spermatogonia and leptotene spermatocytes (Fig. 5). The three types of spermatogonia could not be differentiated based on differences in PNA affinities. Although the cytoplasm of the zygotene spermatocytes had less affinity for PNA than the leptotene spermatocyte, the former cell type stained sufficiently enough to differentiate it from the poorly stained pachytene and diplotene spermatocytes. Spermatids, regardless of the stage of spermiogenesis, either failed to stain or possessed minor affinity to PNA. Interestingly, there was no affinity of PNA for any cell type in the SE of the mature chicken (unpublished observations). 
The affinities of other lectins to the SE cell types failed to provide specific lectin markers. Con A stained all the cells of the SE uniformly while BS-1, WPA, and SBA highlighted the cells and connective tissue elements forming the wall of the seminiferous tubules. A distinguishing characteristic of SBA was its selective affinity for a subpopulation of lymphocytes observed singly or in patches of diffuse lymphoid tissue in the interstitial spaces.

\subsection{Fluorescence microscopy}

Here we focused primarily on differentiating the cells of the SE based on nuclear morphology in either fresh unfixed dispersed preparations of testicular tissue or deparaffinized histological sections of testes tissue. A general observation is that in deparaffinized sections the nucleolus and heterochromatin stained intensely but not the euchromatin. Alternatively, in unfixed dispersed cells, the euchromatin fluoresced enough to decrease the resolution of the heterochromatin patterns.

Spermatogonia were the most difficult to differentiate in the unfixed dispersed preparations. Their nuclei revealed some heterochromatin patterns but diameter was its most distinguishing characteristic. The three types of spermatogonia could not be identified in these preparations. In deparaffinized sections, the type $A_{p}$ and type $B$ spermatogonia were evident but the type $A_{d}$ spermatogonia were not discernible. Spermatocytes and round and elongating spermatids were easily discernible in both preparations.

\subsection{Other cell markers}

As note previously, alkaline phosphatase was highly selective for Leydig cells and non-reactive with other cells in the testes. c-kit, like PNA, was specific for spermatogonia in 8 week and younger males (Fig. 8). The c-kit staining was more diffuse in the mature SE.

\section{Discussion}

One of primary objectives of this study was to discover cytological and /or cytochemical characteristics of the three types of spermatogonia that would be useful in their identification in cell dispersions and cultures. Through the use of 1-2 $\mu \mathrm{m}$ thick plastic sections, fluorescence microscopy, and cell labeling techniques we extended and further defined the histology and cytochemistry of the turkey SE (see Noirault et al., in press). Given our current collective observations, we re-evaluated and have adapted the nomenclature of Lin and Jones (1992) to identify the three types of spermatogonia. Based on TEM, Lin and Jones (1992) subdivided type Ap spermatogonia into $A_{p 1}$ and $A_{p 2}$ based on the relative absence of organelles in $A_{p 1}$ to $A_{p 2}$. However, by light microscopy, nuclei were the primary characteristic differentiating the types of spermatogonia. Within the turkey, type $A_{d}$ spermatogonia, were infrequently observed, were single and not in groups, were intimately associated with the basement membrane of the SE, and were characterized by the smallest nuclear diameters and the most densely staining nucleus compared to the types $A_{p}$ and $B$ spermatogonia. Furthermore, in contrast to the observations reported Noirault et al. (in press) and Lin and Jones (1992) type $A_{d}$ nuclei were round to oval and not exclusively flattened ovals in shape. Given the above, we postulate that the turkey type $A_{d}$ spermatogonia possess the characteristics of the germ-line stem cell (type $A_{s}$ spermatogonia) described in the mammalian testicular SE by Spradling et al. (2001), and therefore may be the stem cell spermatogonia in the adult turkey. Thus, while some morphological characteristics of the turkey type $A_{d}$ spermatogonia 
differ from those described for the Japanese quail type $A_{d}$ spermatogonia (Lin and Jones, 1992) we concur with the latter authors that the type $A_{d}$ is the spermatogonial stem cell in these two species.

The differentiation of type $A_{p}$ from type $B$ spermatogonia was based on nuclear size differences and distribution and extent of heterochromatin and euchromatin. In bright-field microscopy, type $A_{p}$ either were without or with 1-2 nucleoli, and possessed a pale granular euchromatin with little heterochromatin. Correlating bright-field images with those of fluorescence helped with the identification of type $A_{p}$ from type $B$ spermatogonia.

Lectin staining of the SE from pre-pubertal and adult turkeys was primarily limited to PNA, which was specific for spermatogonia and, to a lesser extent, primary spermatocytes, and WGA, which was specific for Sertoli cells. The remaining lectins evaluated were either non-specific highlighting all the cells of the SE interstitial lymphocytes, and/or the connective tissues forming the seminiferous tubule walls and interstitial blood and lymph vessels. Strong PNA staining of the spermatogonia and the pre-leptotene spermatocytes and the progressive decrease in the staining intensity from the leptotene to the pachytene stages of meiotic prophase through spermatid formation indicates that surface glycoconjugates containing terminal $\beta$-D-galactose- $(1,3)-N$ acetyl-galactosamine residues (Lotan et al., 1975) were less diffuse and became concentrated in small discrete areas within late spermatocytes and early spermatids. Failure of BS-I, which has specificities to $\alpha-N$-acetyl-D-galactosamine residues, to stain cells of the SE indicates the high degree of specificity each lectin has for its receptor sugar.

The specificity of PNA to the turkey spermatogonia and early spermatocytes contrasts to the more general staining of PNA to mouse testicular germ cells (Maekawa and Nishimune, 1985). Using this PNA specificity as the basis for an affinity cell separation procedure, Maekawa and Nishimune (1985) have obtained highly enriched germ cell and somatic cell fractions. Soybean agglutinin will also bind to $N$-acetyl-D-galactosamine and to a lesser extent to D-galactose (Lis et al., 1970). Yet, SBA staining of the SE was absent. Menghi et al. (1985) likewise noted that PNA and SBA failed to stain the same cells in the rabbit oviduct and concluded that there was no overlap of the specificity of these two lectins.

Wheat-germ agglutinin staining was limited to the apical cytoplasm of cells assumed to be Sertoli cells in the seminiferous tubules of pre-pubertal males. This staining pattern was observed in all seminiferous tubules from immature males examined except in the 15-week old male exhibiting the onset of spermatogenesis. Here the supra-nuclear and apical cytoplasm of Sertoli cells stained in a manner similar to that observed in mature males. Such extensive staining indicates the widespread presence of macromolecules containing $N$-acetyl-D-glucosamine and/or $\mathrm{N}$-acetyl-neuraminic acid residues. This appears to be associated with the onset of spermatogenesis and may indicate specialized Sertoli cell activities such as glycoprotein and/or glycolipid synthesis.

With the ability to partially differentiate specific cell types in the turkey SE, our work will progress to the isolation of cells of interest, in particular, the spermatogonia. Techniques to separate populations of mammalian germ and testicular somatic cells (reviewed by Meachem et al., 2001) include the use of cell specific probes and enzyme markers (Falciatori et al., 2005). With the turkey, we are currently using PNA magnetic beads in an attempt to collect an enriched population of spermatogonia and spermatocytes. Interestingly, PNA does not preferentially bind to the same germ cells in sections of chicken testes. c-kit also binds to spermatogonia in all turkey males examined but to a greater extent in the pre-pubertal testes. We have adapted a technique described by Van der Wee et al. (2001) using magnetic beads with affinity to the c-kit binding sites to isolate spermatogonia from pre-pubertal and adult turkey testes. 


\section{References}

Aire, T.A., Olowo-okorun, M.O., Ayeni, J.S., 1980. The seminiferous epithelium in the guinea fowl (Numida meleagris). Cell Tissue Res. 205, 319-325.

Arenas, M.I., Madrid, J.F., Bethencourt, F.R., Fraile, B., Paniagua, R., 1998. Lectin histochemistry of the human testis. Internal J. Androl. 21, 332-342.

Arya, M., Vanha-Perttula, T., 1984. Distribution of lectin binding in rat testes. Andrologia 16, 495-508.

Arya, M., Vanha-Perttula, T., 1986a. Postnatal development of lectin-binding pattern in the rat testis and epididymis. Acta Anat. 127, 100-109.

Arya, M., Vanha-Perttula, T., 1986b. Comparison of lectin-staining pattern in testes and epididymis of gerbil, guinea pig, mouse, and nutria. Am. J. Anat. 175, 449-469.

Bosman, F.T., Lindeman, J., Kuiper, G., vander Wal, A., Kreunig, J., 1977. The influence of fixation on immunoperoxidase staining of plasma cells in paraffin sections of intestinal biopsy specimens. Histochemica 53, 57-62.

Brillard, J.P., 1981. Influence de la photoperiode quotitdienne sur le developpement des testicules et sur l'establissement de la spermatogenese chez la pintade. Thesis, Universite Tours, Tours France, (in French).

Clermont, Y., 1958. Structure de l'epithelium seminal et mode de renouvellement des spermatogonies chez le canard. Arch. Anat. Microsc. Morph. Exp. 47, 47-66 (in French).

Cooksey, E.J., Rothwell, B., 1973. The ultrastructure of the Sertoli cell and its differentiation in the domestic fowl (Gallus domesticus). J. Anat. 114, 329-345.

de Reviers, M., 1971. Le developpement testiculaire chez le coq II. Morphologie de l'epithelium seminifiere et esablissement de la spermatogenese. Ann. Biol. Anim. Biochem. Biophys. 11, 531-546 (in French).

Dobrinski, I., 2005. Germ cell transplantation and testis tissue xenografting in domestic animals. Anim. Reprod. Sci. 89, $137-145$.

Falciatori, I., Borsellino, G., Haliassos, N., Boitani, C., Corallini, S., Battistini, L., Bernardi, G., Stefani, M., Vicini, E., 2005. Identifying and enrichment of spermatogonial stem cells displaying side population phenotype in immature mouse testis. FASEB J., express article 10.1096/fj.03-0744fje. Published on line December 19, 2003.

Gunawardana, V.K., 1977. Stages of spermatids in the domestic fowl: a light microscope study using araldite sections. J. Anat. 123, 351-360.

Hofmann, M.C., Braydich-Stolle, L., Dettin, L., Johnson, E., Dym, M., 2005. Immortalization of mouse germ line stem cells. Stem Cells 23, 200-210.

Jones, R.C., Lin, M., 1993. Spermatogenesis in birds. Oxford Rev. Reprod. Biol. 15, 233-264.

Lin, M., Jones, R.C., 1992. Renewal and proliferation of spermatogonia during spermatogenesis in the Japanese quail, Coturnix coturnix japonica. Cell Tissue Res. 267, 591-601.

Lis, H., Sela, B.A., Sachs, L., Sharon, N., 1970. Specific inhibition by $N$-acetyl-D-galactosamine of the interaction between soybean agglutinin and animal cell surfaces. Biochem. Biophys. Acta 211, 582-585.

Lotan, R., Skutelsky, E., Danon, D., Sharon, N., 1975. The purification, composition, and specificity of the anti-T lectin from peanut (Arachis hypogaea). J. Biol. Chem. 250, 8518-8523.

Maekawa, M., Nishimune, Y., 1985. Separation of germ cells from somatic cells in mouse testis by affinity for a lectin peanut agglutinin. Biol. Reprod. 32, 419-425.

Meachem, S., von Schonfeldt, V., Schlatt, S., 2001. Spermatogonia: stem cells with a great perspective. Reproductive $121,825-834$.

Menghi, G., Bondi, A., Materazzi, G., 1985. Distribution of lectin binding sites in rabbit oviduct. Anat. Rec. 211, $279-284$.

Noirault, J., Brillard, J.P., Bakst, M.R., in press. Spermatogenesis in the turkey (Meleagris gallopavo): quantitative approach in immature and adult males subjected to various photoperiods. Theriogenology.

Pastor, L.M., Morales, E., Polo, L.A., Calvo, A., Pallares, J., de la Viesca, S., 2003. Histochemical study of glycoconjugates in active and photoperiod regressed testis of hamster (Mesocricetus auratus). Acta Histochem. 105, 165-173.

Roca, J., Mezquita, C., 1989. DNA topoisomerase II activity in nonreplicating, transcriptionally inactive, chicken late spermatids. EMBO J. 8, 1855-1860.

Spradling, A., Drummond-Barbosa, D., Kai, T., 2001. Stem cells find their niche. Nature 414, 98-104.

Trefil, P., Micaková, A., Mucksová, J., Hejnar, J., Brillard, J.P., Bakst M.R., Kalina, J., Poplštein, M., submitted for publication. Restoration of spermatogenesis and male fertility by transplantation of dispersed testicular cells in the chicken. Biol. Reprod.

Van der Wee, K.S., Johnson, E.W., Dirami, G., Dym, M., Hofmann, M.C., 2001. Immunomagnetic isolation and long term culture of mouse Type A spermatogonia. J. Androl. 22, 696-704.

Zlotnik, I., 1947. The cytoplasmic components of germ-cells during spermatogenesis in the domestic fowl. Quart. J. Microsc. Sci. 77, 353-365. 